\title{
Heavy-mineral analysis as a tool in tephrochronology, with an example from the La Sal Mountains, Utah, U.S.A.
}

\author{
Arno Kleber \\ Technische Universität Dresden, Geography Institute, Dresden, Germany; e-mail: Arno.Kleber@tu-dresden.de
}

\begin{abstract}
An essentially pure tephra layer on a steep slope in the La Sal Mountains, Utah, U.S.A., is correlated with the 1.65 Ma old Guaje Tephra derived from the Jemez Mountains, New Mexico, U.S.A. The heavy-mineral contents and glass shards in sediments beneath the La Sal tephra layer indicate that tephra constituents are contained in deposits considerably older than the pure layer. This suggests that tephra material may become reworked while retaining its pure character, possibly due to laminar transport or to dislocation in a frozen condition. This raises the need to handle tephrochronological findings with great care.
\end{abstract}

Key words: heavy-mineral analysis, tephrochronology, reworking history, relative dating, palaeopedology

\section{Introduction}

The term 'tephra' is used for all airborne solid material derived from volcanic eruptions (Porarinsson, 1944). Tephrochronology uses discrete layers of tephra within sedimentary successions as an indicator of age, which is facilitated by the fact that volcanic eruptions usually are well datable themselves, and that their tephras are often quite certainly identified by means of the chemical composition of glass shards or minerals through electron microprobe analysis (Izett, 1981; Sarna-Wojcicki \& Davis, 1991). Tephrochronology has evolved into an important tool in geochronology (Froese et al., 2008), particularly where tephra beds are frequent and distinguishable such as in Iceland (Pórarinsson, 1979), New Zealand (Vucetich \& Pullar, 1969), and in the western U.S.A. (Izett, 1981; Sarna-Wojcicki \& Davis, 1991). It is a major tool for dating and synchronizing sedimentological archives (Lowe, 2011).

However, occasionally tephras are admixed to other substrates in a way that their identification gets difficult, especially if their glass shards have been weathered during subsequent pedogenesis. A famous case is the Allerød Laacher-See Tephra (LST) Complex in Central Europe. Its known distribution in the form of discrete layers is depicted in Figure 1. Though not preserved as a layer anymore, it is known to have been spread much farther. This knowledge stems from heavy-mineral analyses: due to the fact that the tephra contains a rather unique combination of minerals (typically brown amphibole, titanite, and aegirine-augite), it may be identified even without discrete layers and preserved shards. Figure 1 gives some examples from the literature and from own unpublished analyses, demonstrating the possibility to trace the tephra com- 


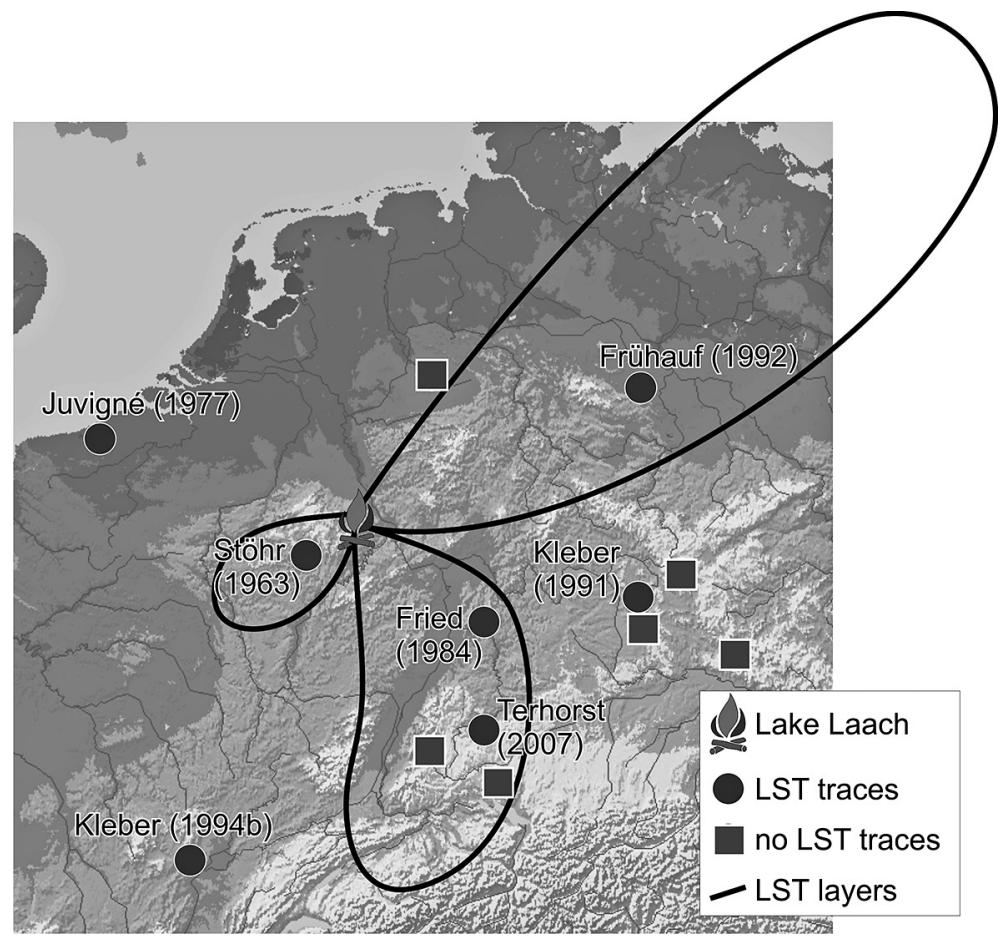

Fig. 1. Distribution of Laacher-See Tephra layers in Central Europe. LST layers: distribution of discrete layers of Laacher-See Tephra of at least $0.5 \mathrm{~cm}$ thick (after Van den Bogaard \& Schmincke, 1985); LST found: admixed heavy minerals of the Laacher-See Tephra found in the uppermost layer of a slope deposit (selected cases, with reference); no LST found: LST minerals not found in a sample of at least 200 transparent grains (unpublished own analyses).

ponents outside of the distribution of discrete layers. Since Schönhals (1957) and Stöhr (1963), Semmel has published a vast number of analyses of LST minerals in the uppermost layer of slope deposits from the mountains around Lake Laach (most recently: Semmel, 2003; Semmel \& Terhorst, 2010); they cannot be depicted here in detail because of scale.

Another example of tracing the distribution of tephra components aided by heavy-mineral analyses was given by Kleber (1999). He reported cummingtonite as a heavy mineral traces of which may frequently be found in certain layers of slope deposits in and around the northern Great Basin, U.S.A. Cummingtonite may be a stratigraphic marker mineral in that area. It was yielded by Mt. St. Helens, with the first eruption known to contain this mineral (Mullineaux, 1986) around 50,000 years ago (Berger, 1991). Another cummingtonite-bearing eruption occurred around 13,000 years ago (Mullineaux, 1986). Kleber (1999) assumed that the two deposits containing this mineral may be approximately correlated chronologically with those prominent eruptions, because the principles of tephrochronology may be applied to cryptotephra as well as to discrete layers (Lowe, 2011). However, this interpretation certainly is less reliable than the previous one regarding Laacher-See Tephra, because it is based on just a single, though rather uncommon, mineral instead of a combination of three.

\subsection{A new approach}

Here I present a new approach to use heavy-mineral analysis as a tool for tephrochronology, inasmuch as I do not attempt tracing tephra constituents beyond the known regional distribution of the tephra layers, but try to locate the first occurrence of constituents of a particular tephra within a single, though complex, sediment profile.

Provided a tephra layer appears to be uncontaminated with other material admixed during reworking of a first-deposited tephra layer, the danger of reworking of tephra material from another location considerably after its primary deposition is rarely considered, because it is usually assumed that the tephra necessarily would have become mixed with the much more voluminous local clastic load; rather, it is assumed that reworking could only have occurred shortly after the initial eruption and deposition of the tephra (Sarna-Wojcicki \& Davis, 1991). Thus, in the case of discrepancies with independent age estimates, the date 
provided by an uncontaminated tephra layer is usually given preference (e.g., Davis et al., 1986).

\subsection{The La Sal Mountains tephra layer}

A tephra layer, in the following referred to as the La Sal Mountains (LSM) tephra layer, found in the north-western LSM, Utah, U.S.A. (located $38^{\circ} 36^{\prime} \mathrm{N}, 109^{\circ} 22^{\prime} 30^{\prime \prime} \mathrm{W}$, at an elevation of $2130 \mathrm{~m}$ a.s.1., on a $22^{\circ}$ steep slope), is exposed by a road cut of the Manti-La Sal circuit (Figs 2 and 3). It has previously been taken for a mature carbonate-enriched soil horizon due to its bright colour (M. Ross, mapping geologist of the UGMS, pers. comm., 1990). The relative position of such a mature calcic horizon appeared unlikely in the light of previous stratigraphic evidence from nearby areas (Kleber, 1994a); upon closer look, this layer turned out to consist of tephra. The chemical composition of its glass shards is close to that of the approx. 1.65 Ma old (Spell et al. 1990) Guaje Tephra (Table 1), derived from the Jemez Mountains, New Mexico. An alternative match is the approx. 1.25 Ma old (Phillips et al., 2007) Tsankawi Tephra from the same mountain range (Slate et al., 2007). However, particularly the similarity in iron content (Table 1) supports the correlation of the LSM tephra layer with the Guaje rather than with the Tsankawi Tephra (A.M. Sarna-Wojcicki, USGS, written comm., 1993).

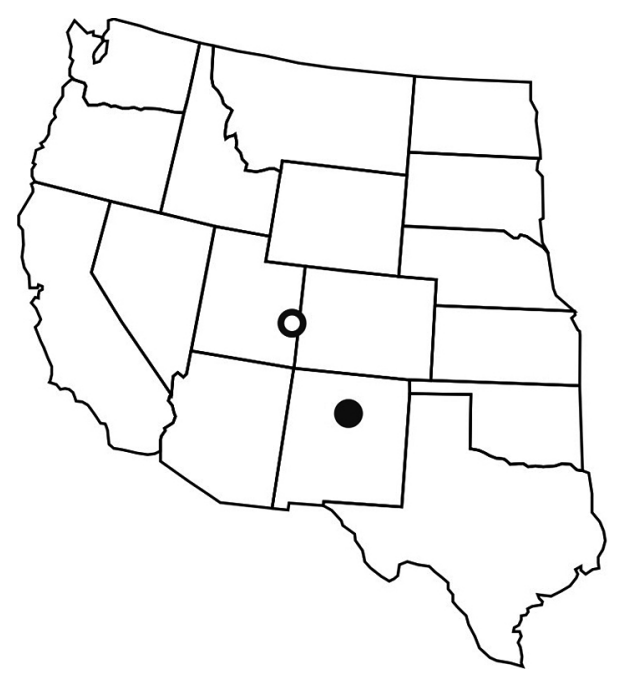

Fig. 2. Western United States with locations of the La Sal Mountains, Utah (open circle) and the Jemez Mountains, New Mexico (closed circle).
Table 1. Electron microprobe analyses of glasses from the LSM Tephra and the closest matches, the Guaje and the Tsankawi Tephras. See Sarna-Wojcicki et al. (2005) for sample preparation and analytical methods. Analyst C.E. Meyer, US Geological Survey, Menlo Park, sample NLSM-109. Values given are weight-percent oxide, recalculated to $100 \%$ fluid-free basis. About 20 individual glass shards or points were analysed for each sample.

\begin{tabular}{lcccc}
\hline & $\begin{array}{c}\text { LSM } \\
\text { tephra }\end{array}$ & Guaje & Tsankawi Tsankawi \\
\hline $\mathrm{SiO}_{2}$ & 77.16 & 76.64 & 76.81 & 77.32 \\
$\mathrm{Al}_{2} \mathrm{O}_{3}$ & 12.21 & 12.49 & 12.18 & 11.43 \\
$\mathrm{Fe}_{2} \mathrm{O}_{3}$ & 1.49 & 1.45 & 1.60 & 1.64 \\
$\mathrm{MgO}$ & 0.01 & 0.00 & 0.01 & 0.00 \\
$\mathrm{MnO}$ & 0.06 & 0.06 & 0.05 & 0.07 \\
$\mathrm{CaO}$ & 0.27 & 0.28 & 0.28 & 0.27 \\
$\mathrm{TiO}_{2}$ & 0.08 & 0.06 & 0.05 & 0.04 \\
$\mathrm{Na}_{2} \mathrm{O}$ & 4.37 & 4.49 & 4.66 & 4.64 \\
$\mathrm{~K}_{2} \mathrm{O}$ & 4.35 & 4.52 & 4.36 & 4.59 \\
similarity & - & 0.9740 & 0.9707 & 0.9554 \\
coefficient & - & & & \\
\hline
\end{tabular}

In the field and under the microscope, the tephra layer shows only a slight indication of weathering; in its core there is no such indication at all (Fig. 4). This preservation would be unlikely if the tephra layer had been as close to the surface since $1.65 \mathrm{Ma}$ as it is now. Thus, the question arises whether material originally overlying the LSM tephra layer has been eroded or whether the tephra layer, despite its pure appearance, was reworked considerably after it had been originally deposited and is in a secondary position in this profile. The present contribution discusses evidence for the latter hypothesis, along with consequences for tephrochronology in steep relief.

\section{Methods}

Particle sizes were determined by sieving and the pipette method, using $\mathrm{Na}_{4} \mathrm{P}_{2} \mathrm{O}_{7}$ as a dispersant, after removing carbonate by treatment with acetic acid. However, in the following the discussion of the texture will be restricted to the fine-sand particle-size class (0.063-0.2 mm), which is indicative of the LSM tephra layer. The carbonate content was determined with a gas-volumetric Scheibler apparatus (Page et al., 1982). 

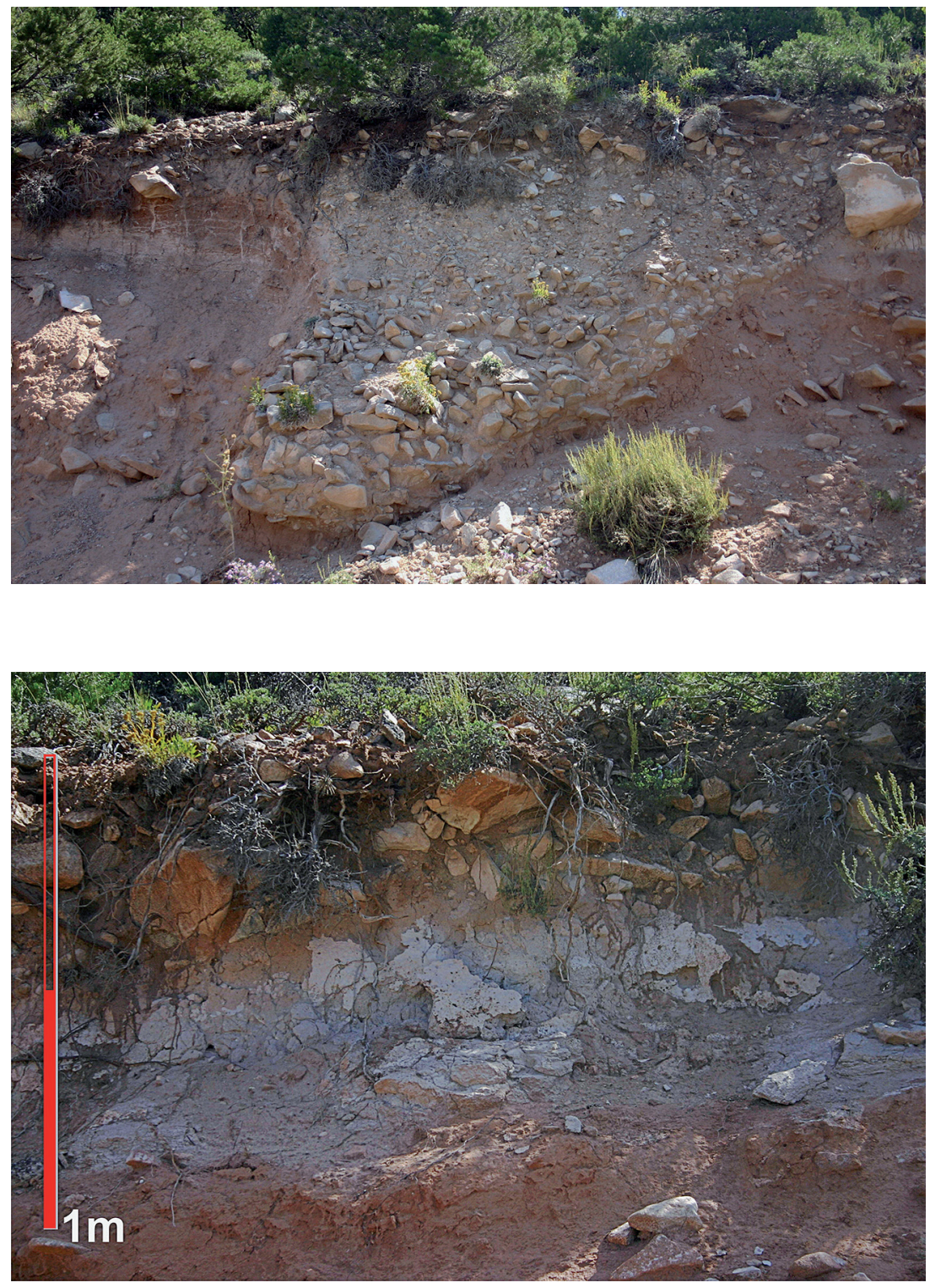

Fig. 3. Exposure under study in the La Sal Mountains.
Fig. 4. La Sal Mountains Tephra layer as exposed in the right part of the profile.

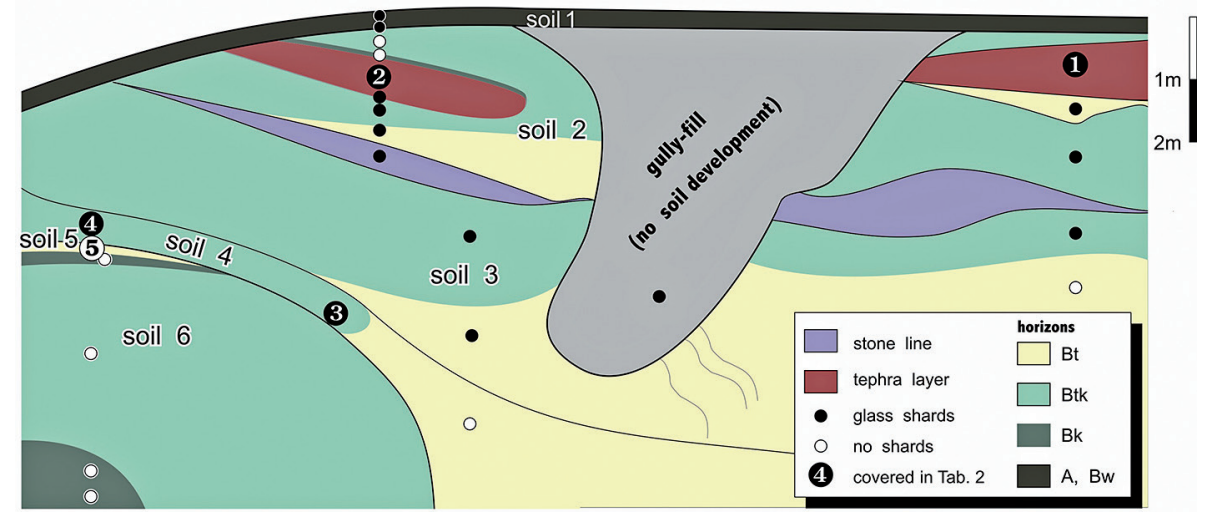

Fig. 5. Sketch of soils and deposits of the exposure under study. The scale is approximate. Circles indicate samplings; filled circles indicate the presence of glass shards. Carbonate concentrations are $<10 \%$ (Bt horizons), $10-50 \%$ (Btk) and $>50 \%$ (Bk) of the fine earth fraction. There is no visible soil development in the tephra layers and in the gully fill. In the stone lines Btk horizons are present. 
Light minerals were microscopically counted on a representative fraction of the whole sample. For heavy-mineral analysis, heavy particles of the 100-200 $\mu \mathrm{m}$ size fraction, separated by floatation in bromoform, were embedded in resin (refraction index 1.67) for microscopic examination (cf. Marcinkowski \& Mycielska-Dowgiało, 2013). Approximately 200 nonopaque grains were identified per sample.

\section{Results and discussion}

Where the LSM tephra layer was found, the exposure consists of several soil horizons that were formed mainly from loess-dominated slope deposits during various soil-forming episodes (Fig. 5). Various palaeosols can be distinguished by means of their compound clayand carbonate-enriched (argillic and calcic, respectively) horizons: the carbonate in these compound horizons must have accumulated after the argillic properties had been formed, because carbonate enrichment and clay illuviation cannot occur simultaneously in the same horizon, and clay translocation is only possible during or after the carbonate has been depleted (see Kleber, 2000, for detailed reasoning). Furthermore, a much warmer soil-temperature regime than the area is experiencing now would have been needed to form calcic horizons reaching as deep as in this profile, provided the entire parent material of the soil was to be seized (cf. McFadden \& Tinsley, 1985). Both lines of reasoning lead to the interpretation that the parent material of each soil was deposited after the argillic properties in the respective underlying soil had already been formed, which implies that the latter is part of a palaeosol (cf. Kleber, 2000). Accordingly, the soils in this profile most likely were formed during a considerable span of time, probably covering hundreds of thousands of years.

The heavy-mineral composition of the tephra layer is dominated by clinopyroxene (\# 1; sample numbers refer to Table 2 and Fig. 6, soil numbers to Fig. 6), which is less frequent in loess-dominated slope deposits (\# 5), where calcic amphibole and titanite predominate instead. Another mineral is probably unique to
Table 2. Selected properties of the LSM Tephra (1) and of some samples (2-5).

\begin{tabular}{|c|c|c|c|c|c|}
\hline Number & 1 & 2 & 3 & 4 & 5 \\
\hline heavy mineral & \multicolumn{5}{|c|}{ (\% of transparent grains) } \\
\hline clinopyroxene & 74.1 & 44.2 & 47.5 & 35.7 & 16.1 \\
\hline green calcic amphibole & 9.9 & 17.9 & 18.8 & 28.6 & 61.1 \\
\hline hypersthene & 8.8 & 3.8 & 4.2 & 0.0 & 0.0 \\
\hline titanite & 5.0 & 30.5 & 27.0 & 33.3 & 22.2 \\
\hline others & 2.2 & 3.6 & 2.5 & 2.4 & 0.6 \\
\hline $\begin{array}{l}\text { fine sand } \\
\text { (\% of fine earth) }\end{array}$ & 54.7 & 36.0 & 34.9 & 22.0 & 16.4 \\
\hline $\begin{array}{l}\text { glass shards } \\
\text { (\% of light grains) }\end{array}$ & 95 & 80 & 80 & 3 & 0 \\
\hline
\end{tabular}

See Figure 3 for the position of the selected samples in the profile. Analyst R. Schill, Geomorphology Laboratory, Bayreuth University. $1=$ pure tephra; $2,3=$ mixture of slope deposit and tephra; 4 = slope deposit with tephra traces; 5 = pure slope deposit.

the LSM tephra layer, as it is essentially absent in other samples from this area: orthopyroxene with the petrographic appearance of hypersthene (Kleber, 1992, and unpublished analyses). Among the light minerals are many glass shards. The grain-size distribution of the tephra particles peaks in the fine-sand fraction, whereas the surrounding slope deposits largely contain coarse silt. Two other samples (\# 2 and \# 3) also contain conspicuous amounts of glass shards, fine sand, and clinopyroxene, as well as some orthopyroxene. Sample \# 2 stems from approximately the same stratigraphic position as sample \# 1 but is more contaminated with surrounding loessic material, whereas sample \# 3 stems from a small sand lens within soil 4 . Sample \# 4 is from the same soil and contains some tephra constituents, i.e. glass shards, visible in the field aided by a magnifying glass. Sample \# 5 is from soil 5 and is free of tephra material.

Glass shards occur in various layers (Fig. 5) down to and including the parent material of soil 4 , whereas they were found to be absent beneath soil 4 . Contrary to other textural classes and minerals (not shown), there are significant correlations among the tephra constituents: glass shards, clinopyroxene, and fine sand (Fig. 6). Increases in one component are accompanied by significant proportional increases in the others in the entirety of samples. This is in- 

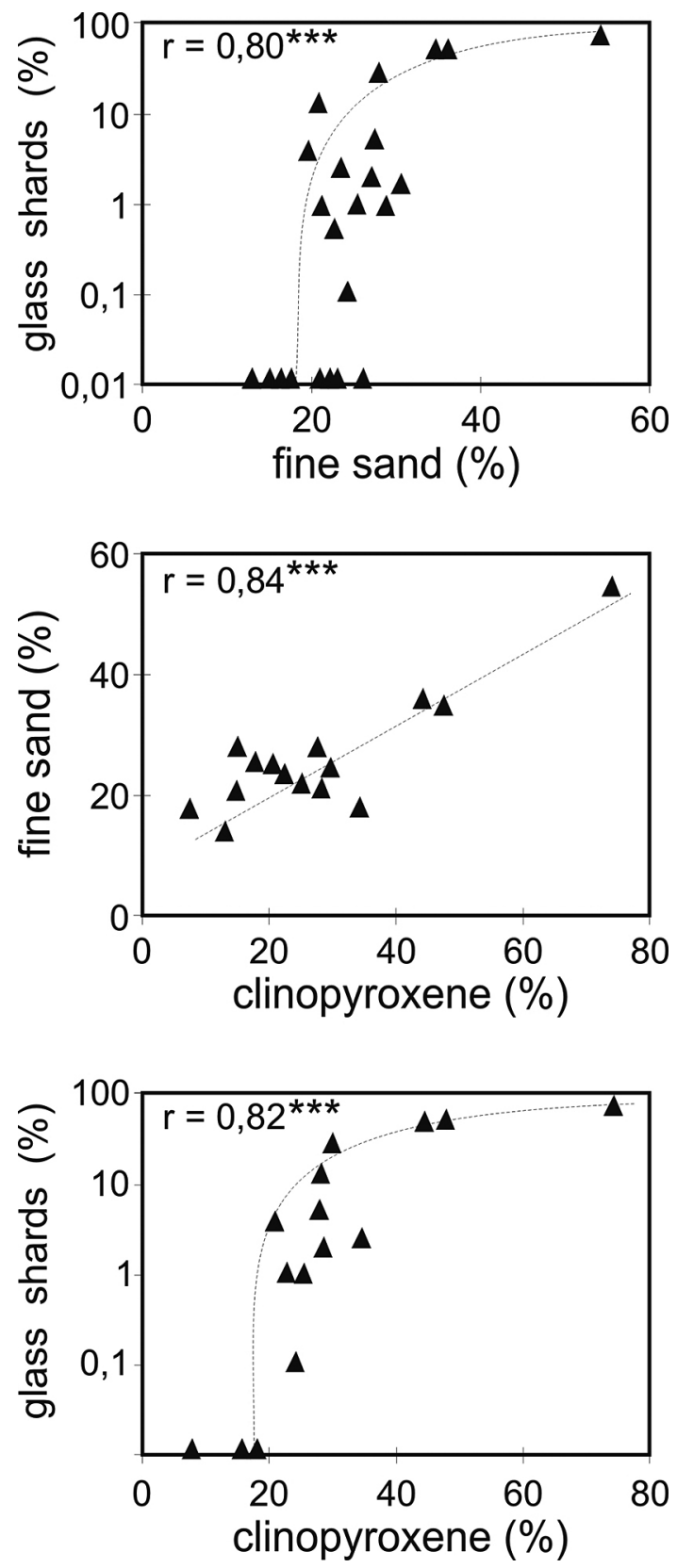

Fig. 6. Correlation of tephra constituents. Top: glass shards (logarithmic scale) vs. fine sand; middle: fine sand vs. clinopyroxene; bottom: glass shards (logarithmic scale) vs. clinopyroxene. Linear (note logarithmic scale where applicable) regressions are displayed and $\mathrm{r}$-values are computed. ${ }^{* *}$ : level of significance $>99.9 \%$.

terpreted as indicating that these components have one major source in common. Presumably, a layer of the Guaje tephra has yielded particles from upslope since the time of the formation of the parent material of soil 4 already, and became finally eroded and reworked when the parent material of soil 2 was deposited. Up- slope from the exposure, the loess-rich slope deposits wedge out within a few metres, and no occurrence of a first-deposition tephra layer could be found, which is, therefore, assumed to have been eroded completely.

Gelifluction could account for this en-bloc reworking, as it is able to dislocate matter without mixing it with neighbouring materials:

(1) The tephra material may have been transported as a frozen block. Due to its porous structure, the thawing behaviour of frozen tephra likely differs remarkably from surrounding materials. Though gelifluction usually dislocates thawed material above the underlying frozen substrate (French, 2007), delayed thawing of tephra material relative to its surroundings (similar to strongly weathered rock fragments dislocated undisturbed by gelifluction as described by Kleber, 1997) may have resulted in dislocation affecting it as a still frozen block embedded in unfrozen matter.

(2) Alternatively, gelifluction might have been laminar. Laminar dislocation also does not mix neighbouring materials (Jaesche et al., 2003), and there is evidence that it is frequent in gelifluction sediments (Kleber et al., 2013). However, at its lateral edges the tephra layer is well mixed with other materials, as depicted with sample \# 2 in Table 2.

\section{Conclusions}

The tephra constituents down to soil 4 indicate that tephra material was admixed to the parent material of soil 4 , i.e. significantly earlier than the pure tephra layer embedded into soil 2 was formed. This suggests that tephra material may be reworked quite a long time after its primary deposition, nevertheless retaining an essentially pure character. Thus, age determinations based solely on a pure tephra layer may yield incorrect results due to non-apparent reworking of tephra material. Heavy-mineral analyses may yield evidence of tephra constituents throughout a profile, and may allow to fathoming a reworking history.

Therefore, it is necessary to interpret tephra layers - even if they appear pure and uncontaminated with surrounding material - with 
great care, similarly to other relative-dating methods. This certainly holds true for tephra layers preserved in steep relief, as demonstrated in this study; but it has to be tested whether similar caveats may apply to low slope angles as well, because slope dynamics able to transport such material frozen or by laminar gelifluction may act on essentially any slope regardless of its inclination (French, 2007).

\section{Acknowledgements}

I thank M. Ross, Utah Geological and Mineralogical Survey, who arranged for the analyses of the LSM tephra layer and for some excellent days in the field. I am indebted to A.M. Sarna-Wojcicki, United States Geological Survey, for very helpful written communication on the tephra analyses, and to R. Schill, Geomorphological Laboratory, University of Bayreuth, who performed the other analyses including heavy-mineral analyses. The research was funded by the German Research Foundation.

\section{References}

Berger, G.W., 1991. The use of glass for dating volcanic ash by thermoluminescence. Journal of Geophysical Research B12, 19705-19720.

Davis, O.K., Sheppard, J.C. \& Robertson, S., 1986. Contrasting climatic histories for the Snake River Plain, Idaho, resulting from multiple thermal maxima. Quaternary Research 26, 321-339.

French, H., 2007. The periglacial environment ( $3^{\text {rd }}$ ed.). Wiley, Chichester, $480 \mathrm{pp}$.

Fried, G., 1984. Gestein, Relief und Boden im Buntsandstein-Odenwald. Frankfurter Geowissenschaftliche Arbeiten Serie D 4, 1-201.

Froese, D.G., Slate, J., Knott, J.R. \& Lowe, D.J., 2008. Global tephra studies. Quaternary International 178 (John Westgate and Andrei Sarna-Wojcicki commemorative volume), 1-320.

Frühauf, M., 1992. Die Bedeutung jungdryaszeitlicher geomorphologischer Prozesse für die Landschaftsgenese in den Mittelgebirgen. Zeitschrift für die geologische Wissenschaft 20, 99-104, 239-244.

Izett, G.A., 1981. Volcanic tephra beds: recorders of Upper Cenozoic silicic pyroclastic volcanism in the Western United States. Journal of Geophysical Research 86, 10200-10222.

Jaesche, P., Veit, H. \& Huwe, B., 2003. Snow cover and soil moisture controls on gelifluction in an area of seasonal frost, Eastern Alps. Permafrost and Periglacial Processes 14, 399-410.
Juvigné, E., 1977. Zone de dispersion et âge des poussières volcaniques du Tuf de Rocourt. Annales de la Société Géologique de la Belgique 100, 13-22.

Kleber, A., 1991. Die Gliederung der Schuttdecken am Beispiel einiger oberfränkischer Bodenprofile. Bayreuther Bodenkundliche Berichte 17, 83-105.

Kleber, A., 1992. Deckschichten und Böden in den nordwestlichen La Sal Mts., Utah, USA. Bonner Geographische Arbeiten 85, 114-129.

Kleber, A., 1994a. On the paleoecology of the northern Great Basin and adjacent Rocky Mountains. Zeitschrift für Geomorphologie, Neue Folge 38, 421-434.

Kleber, A., 1994b. Traces of Laacher See Tephra in cover beds near Chagny, Bourgogne, France. Revue de Géomorphologie Dynamique 45, 71-76.

Kleber, A., 1997. Cover-beds as soil parent materials in mid-latitude regions. Catena 30, 197-213.

Kleber, A., 1999. Cover beds as relative-dating tools - examples from the western USA. Zeitschrift für Geomorphologie, Neue Folge 43, 51-59.

Kleber, A., 2000. Compound soil horizons with mixed calcic and argillic properties - examples from the northern Great Basin, USA. Catena 41, 111-131.

Kleber, A., Terhorst, B., Bullmann, H., Hülle, D., Leopold, M., Müller, S., Raab, T., Sauer, D., Scholten, T., Dietze, M., Felix-Henningsen, P., Heinrich, J., Spies, E.-D. \& Thiemeyer, H., 2013. Subdued mountains of Central Europe. [In:] A. Kleber \& B. Terhorst (Eds): Mid-latitude slope deposits (cover beds). Elsevier, Amsterdam, 9-93.

Lowe, D.J., 2011. Tephrochronology and its application: a review. Quaternary Geochronology 6, 107-153.

Marcinkowski, B. \& Mycielska-Dowgiałło, E., 2013. Heavy-mineral analysis in Polish investigations of Quaternary deposits: a review. Geologos 19 (this issue), 5-23.

McFadden, L.D. \& Tinsley, J.C., 1985. Rate and depth of pedogenic-carbonate accumulation in soils: formulation and testing of a compartment model. Geological Society of America Special Paper 203, 23-41.

Mullineaux, D.R., 1986. Summary of the pre-1980 tephrafall deposits erupted from Mount St. Helens, Washington State, USA. Bulletin of Vulcanology 48, 17-26.

Page, A., Miller, R. \& Keeney, D. (Eds), 1982. Methods of soil analysis. Part 2. Chemical and micro-biological properties ( $\left.2^{\text {nd }} \mathrm{ed}.\right)$. American Society of Agronomy and Soil, Madison, WI.

Phillips, E.H., Goff, F., Kyle, P.R., McIntosh, W.C., Dunbar, N.W. \& Gardner, J.N., 2007. The ${ }^{40} \mathrm{Ar} /{ }^{39} \mathrm{Ar}$ age constraints on the duration of resurgence at the Valles caldera, New Mexico. Journal of Geophysical Research 112, B8, B08201.

Sarna-Wojcicki, A.M. \& Davis, J.O., 1991. Quaternary tephrochronology. [In:] R.B. Morrison (Ed.): Quaternary nonglacial geology: conterminous U.S. Geological Society of America, Boulder, 93-116.

Sarna-Wojcicki, A.M., Reheis, M.C., Pringle, M.S., Fleck, R.J., Burbank, D., Meyer, C.E., Slate, J.L., Wan, E., Budahn, J.R., Troxel, B. \& Walker, J.P., 2005. Tephra lay- 
ers of Blind Spring Valley and related upper Pliocene and Pleistocene tephra layers, California, Nevada, and Utah - isotopic ages, correlation, and magnetostratigraphy. U.S. Geological Survey Professional Paper 1701, 1-63.

Schönhals, E., 1957. Spätglaziale äolische Ablagerungen in einigen Mittelgebirgen Hessens. Eiszeitalter und Gegenwart 8, 5-17.

Semmel, A., 2003. Der Laacher Bimstuff als Zeitmarke der Landschaftsentwicklung in der Wiesbadener Umgebung. Jahrbuch des Nassauischen Vereins für Naturkunde 124, 95-109.

Semmel, A. \& Terhorst, B., 2010. The concept of the Pleistocene periglacial cover beds in central Europe: a review. Quaternary International 222, 120-128.

Slate, J.L., Sarna-Wojcicki, A.M., Wan, E., Dethier, D.P., Wahl, D.B. \& Lavine, A., 2007. A chronostratigraphic reference set of tephra layers from the Jemez Mountains volcanic source, New Mexico. New Mexico Geological Society Guidebook, 58 $8^{\text {th }}$ Field Conference, Geology of the Jemez Mountains Region 2, 239-247.

Spell, T.L., Harrison, T.L. \& Wolff, J.A., 1990. ${ }^{40} \mathrm{Ar} /{ }^{39} \mathrm{Ar}$ dating of the Bandelier Tuff and San Diego Canyon ignimbrites, Jemez Mountains, New Mexico: temporal constraints on magmatic evolution. Journal of Volcanology and Geothermal Research 43, 175-193.
Stöhr, W.T., 1963. Der Bims (Trachyttuff), seine Verlagerung, Verlehmung und Bodenbildung (Lockerbraunerden) im südwestlichen Rheinischen Schiefergebirge. Notizblatt des hessischen Landesamtes für Bodenforschung 91, 318-337.

Terhorst, B., 2007. Periglacial cover beds and soils in landslide areas of SW-Germany. Catena 71, 467-476.

Pórarinsson, S., 1944. Tefrokronologiska studier på Island [Tephochronological studies on Iceland]. Geografiska Annaler 26, 1-217.

Pórarinsson, S., 1979. Tephrochronology and its application in Iceland. Jökull 29, 33-36.

Van den Bogaard, P. \& Schmincke, H.-U., 1985. Laacher See Tephra: A widespread isochronous late Quaternary tephra layer in central and northern Europe. Geological Society of America Bulletin 96, 1554-1571.

Vucetich, C.G. \& Pullar, W.A., 1969. Stratigraphy and chronology of Late Pleistocene volcanic Tephra beds in Central North Island, New Zealand. New Zealand Journal of Geology and Geophysics 12, 784-837.

Manuscript received: 10 October 2012 Revision accepted: 19 January 2013 